\title{
Syllabus Jurisprudence in the Algerian EFL Classroom
}

\author{
Sara Djamàa \\ Department of English, El-Tarf University, El-Tarf, Algeria
}

\begin{abstract}
While the concept of the syllabus has long ago developed to include mainly the course description, the instructor's contact information, the course objectives, approach, and methodology, the required or recommended materials and readings, the course outline, the grading system, and the course policy, Algerian teachers are still stuck at the raw etymological definition of the syllabus as derived from Greek "syllibos," meaning the course outline. To remedy for the pedagogical sin of depriving students from an invaluable pedagogical document, this article outlines steps to crafting effective course syllabi with a sample syllabus and practical recommendations for the benefit of faculty.
\end{abstract}

Index Terms—syllabus design, Algerian University, EFL classroom, LMD system

\section{INTRODUCTION}

Eight years had passed since the Algerian University embraced the LMD ${ }^{1}$ system in an attempt to keep abreast with the requirements that current educational zeitgeist dictates. While a newborn infant, it was paramount to zero in on the architecture of the system. For eight years and hitherto, we kept reiterating explanations of its structure including the duration of study for different degree levels, the number of semesters, the teaching units, the credits, the continuous evaluation process, tutorial sessions, the grading scale policy, the concept of interdisciplinary bridges, focused make-up exams, and other formal concerns. Come on, folks! We as faculty have had enough of talks about the structural and organizational components of the LMD system. While it might still be useful to tackle these aspects every now and then, it is high time for the core pedagogical canon of the LMD system to take the lion's share in our discussions, and in that we are way lagging behind. The staple motto of the LMD system has been "change the antiquated mentalities!", and yet we are doing poorly in scrutinizing what is implied by embracing a new vision of teaching, hence we are failing to eradicate our old mentalities. Having long enough dissected the fashionable body of the LMD system, let us now turn attention to the lofty pedagogical mentality it is entitled to hold. In this respect, the present paper sheds light on a key pedagogical pillar that current educational trends esteem indispensable while still a pariah in our instructional practices. It is the venerable "course syllabus". In a call to nudge Algerian faculty towards incorporating this precious document into their teaching traditions, the article at hand draws on the literature to detail steps to deftly craft an effective course syllabus and provides key considerations and recommendations regarding its content and use. It is my hope that colleagues respond to my call and seek their own growth along with that of students by establishing the first pillar of an LMD system course.

\section{The Components of An EFFective Syllabus}

While their length, content, and format might differ widely from one instructor to another and from course to course, published scholarship (Altman, 1992; Davis, no date; Developing Course Syllabi, no date; Johnson, 2006; Matejka \& Kurke, 1994; Sinor \& Kaplan, no date; Slattery \& Carlson, 2005; Woolcock, 2006) indicates that effective syllabi share the same skeleton. They usually comprise respectively a description of the course, the instructor's contact information, the course objectives, approach, and methodology, the required or recommended materials and readings, the course outline, and the grading system. The more detailed the course syllabus is, the less conflicts are likely to rise between faculty and students and the smoother the teaching-learning experience will be.

\section{A. Course Description}

This section includes the course name and number if applicable, the credits and coefficient attributed to it, the year and semester when it is offered, and the weekly quantity of instruction devoted to it. With the LMD system, it is useful for the student to know the category of instructional unit the course belongs to: Fundamental, methodology, discovery,

\footnotetext{
${ }^{1}$ LMD is an acronym that stands for Licence-Master-Doctorat which respectively correspond to the BA, Master's, and PhD degree. The LMD system has been adopted by the Algerian University in 2004 as part of the educational reforms that seek conformity with the American and European higher education standards. Studies within this system are organized in terms of semesters instead of trimesters and courses fall under four main teaching units: Fundamental, methodology, discovery, and transversal. Continuous evaluation superseded the practice of assessing students' performance on the mere basis of the final exams, European credits have been introduced to measure students' academic achievement, and descriptive statements of courses accompany the diplomas. Other formal components of the LMD system entail the tutorial sessions and interdisciplinary bridges etc.
} 
or transversal. All this information should match the course listing as it appears on the program offer approved by the Ministry of Higher Education and Scientific Research. Further components of this section include the name of the institution with its logo symbol being an option, the name of the department, the section and group number, the class meeting time and location, information regarding tutorial sessions, and the course URL link or website if applicable. In case you have more than one class taking the same course, make sure you make changes as to the meeting time and location for the different groups you teach.

\section{B. Instructor Information}

The instructor's full name and title constitute the opening components of this section. The LMD system underlines the importance of teachers' availability to students outside the regular classroom meeting time which requires faculty members to provide the class with their contact information, usually their personal phone number and/or an e-mail address. Getting a SIM card and/or creating an alternative e-mail account for professional purposes might be good options in a culture that still favors distant and formal relationships with students. Some teachers might choose to use their personal web page or social networking services to communicate with students. Unlike American universities and colleges where most teachers have offices on campus regardless of their degrees and ranks, the majority of faculty members in the Algerian Universities represented by holders of the Magister or Master's degree and part-time adjunct teachers are not offered this facility. Only a minority amongst full professors and PhD holders can benefit from a work locale of their own. This category of teachers can further include office hours, location, phone and fax number on the syllabus in addition to information on how to schedule an appointment and a statement for encouraging office visits. Faculty can choose to share more personal information with their students such as their detailed background education and professional experience, home phone number (restrictions on its use can be included), and home address (Altman \& Cashin, no date; Johnson, 2006; Sinor \& Kaplan, no date).

\section{Course Objectives}

Crafting thorough course objectives entails considering the end of the course before starting to teach it. The focus of this section is on exposing the knowledge, competencies, skills, and attitudes the course aims at equipping students with, preferably stated from a student's point of view to facilitate learners' understanding of what is expected of them (Johnson, 2006). It tells the learner why he is taking a particular course and reminds the educator why he is teaching it. The minimum to include in this part of the syllabus would be a reiteration of the course goals as stated in the school's or the department's official document of course information (Altman \& Cashin, 1992; Davis, no date). Action verbs --such as verbs in Bloom's taxonomy including: Identify, classify, read, produce, write, describe, discuss, interpret, report, examine, illustrate, recognize, assess, construct, demonstrate, discover, report, analyze, synthesize, evaluate, communicate .....etc. -- endow the course objectives with strength and make them seem more tangible to the learner. Careful attention should be devoted to measuring the course objectives accurately and tailoring them to the time frame granted to the course to guarantee their fulfillment (Johnson, 2006). An explanation of how the course objectives relate to the overall program goals and to students' future professional life is very useful to the learner. This way they get to understand why the course is part of the requirements for their degree.

\section{Course Approach and Methodology}

This part addresses the way the teaching/learning process will take place. How the instructor will approach the course to achieve its objectives, what methodologies he intends to use and what is the rationale behind opting for them, what roles he will assume in the teaching process, what format the course will take: Lecture, lecture and lab, seminar, lecture and TA sessions, discussion, group work, writing workshops, cooperative learning, practice...etc (Sinor \& Kaplan, no date), and what kind of material and facilities will be used in class are part of the questions this area of the syllabus attempts to answer. The other part treats the roles and responsibilities assigned to the learner such as instructions on how to prepare for a class and teachers' expectations from students in class.

\section{E. Course Materials}

This area of the syllabus provides a bibliographic listing of the texts students are required to bring to class. The author's name, the title of the text, the publication year, the publisher, as well as the edition need to be mentioned. It also comprises a listing of any non-print material, supplies and resources that might be required for use in the course such as films, computers, software, flash drives, external hard drives, CDs....etc (Altman \& Cashin, no date; Johnson, 2006; Sinor \& Kaplan, no date). Some faculty might include readings that are useful for the student in that they help him/her better prepare for classes and exams and expand his/her knowledge of the course content while not required of him. Mingling both compulsory and recommended references is effective yet it is important to build a clear dichotomy between the two (Altman \& Cashin, 1992; Davis, no date; Sinor \& Kaplan, no date). Altman \& Cashin (1992) suggest including a note that explains why the selected material is required for the course and that determines the extent to which it will be used. This guides students towards making appropriate decisions on whether to buy the material or borrow it. If known, stating the cost of the needed materials and providing information and guidelines on how to access them such as citing the name and location of a specific bookstore is particularly helpful for students (Sinor \& Kaplan, no date). Tag the material available for loan from the school's library and let the student know what materials needed in 
the course the concerned department will take care of and provide. In case there are no materials required of the students, it is preferable to clearly mention that in the syllabus.

\section{F. Course Schedule/Calendar}

The course schedule is the backbone of the syllabus. It involves an outline of the course content and activities set in a timely manner; the "what"-cum- the "when" of the course agenda. It is usually organized by topics spread over the number of daily or weekly sessions devoted to the course which enables students to know what to expect every class, hence helps them prepare for it beforehand. The course calendar includes the readings students are required to accomplish with citation of the pages or chapters' numbers along with the due dates and some reading-related notes or instructions. Besides, it highlights the material to bring to class on a particular day, important course events along with their dates such as tests, quizzes, exams, guest speakers, and field trips, deadlines for projects, presentations, and assignments, dates of holidays, breaks, and teachers' pre-planned absences (Altman \& Cashin, no date; Johnson, 2006). Key events and dates preferably need to be bolded to draw more attention to them and facilitate their consultation by students (Sinor \& Kaplan, no date). It is helpful, if not necessary, to refer to the academic calendar prepared by the responsible of the LMD domain when crafting the course outline. Sharon Rubin (as cited in The Importance of the Course Syllabus, 2012) calls for an explanation of the rationale for the order in which the course content occurs.

\section{G. The Grading System}

\section{Means of Assessment.}

Grades are what students care most about. Therefore, this section of the syllabus is by far the most salient in their eyes, the most hypnotizing. It is why it needs a lot of thoughtful reflection prior to crafting it. It lists and prescribes the types of assessments students will be exposed to: attendance and class participation, homework assignments, writing projects, oral presentations, portfolios, quizzes, midterm and final exams, group projects...etc (Johnson, 2006). Below is a synopsis of what might be included in the prescription of the means of assessment.

\subsection{Attendance.}

If attendance is included to determine the course grade, notify your students up front. While attendance policy in the LMD system is fixed by decree for all course offerings alike, allowing up to three unexcused or five excused absences, it is paramount that we remind our students of absenteeism regulations on the syllabus and stress the importance of adhering to them. We can provide them with useful links to access statutory texts that give ample details on the number of tolerated absences, the listing of excused absences, and the types of accepted justification forms ...etc. It is useful to give students an academic warning for absenteeism when they come close to consuming the maximum number of tolerated absences. Appended to the present article is a sample of an academic warning document that I usually use in my classes (see the Appendix). I issue two copies of it and keep one for my own record. If you choose that a student's unexcused absence affects his grade, bring it to notice. Your course policy on late arrivals also should be thought of and made clear to students (Altman \& Cashin, no date, Sinor \& Kaplan, no date). Some faculty members don't allow late arrivals and deny the tardy student access to that particular session. If you are one of those teachers, detail your penalty for tardiness: subtracting credits, denying access to class, denying access and counting the tardiness as an absence....etc. “He refused to let me in because I came late to class and worse to worst, I didn't know my tardiness would count an absence. Surprisingly enough, I found myself on the list of dismissed students at the end of the term," a student attests. This is a sample of common student statements that certify for the serious implications tardiness might have on students' coursework if its penalty measures are not communicated to them. Last but not least, explicate your policy regarding students who want to make-up for classes they missed with a group other than theirs.

\subsection{Class Participation.}

In most learning situations, students are expected to stir the waters in class by maintaining active participation in the different activities to fully benefit from the course and internalize its material. Encouraging statements like "don't be afraid to make mistakes!" are inviting and help students get rid of intimidation and embarrassment. Set clear criteria and rubrics on which you base your evaluation of in-class participation such as: preparing material before class, asking and answering teacher and peers' questions, commenting, taking part in classroom discussions and debates....etc.

\subsection{Homework Assignments.}

State clearly how often you plan on assigning homework: on a daily or weekly basis, when completing a whole unit, or whenever needed. Make the due dates eye-catching by bolding them. Clarify your course policy regarding late homework by indicating whether it is accepted or not and whether it is subject to penalty by adversely affecting the student's grade. Indicate if students can make-up for a missed assignment and whether you offer any extra credit work. Guide your class with instructions on how you want them to do the homework with such statements as: "Essay papers should be no longer than two pages long with the introduction and conclusion inclusive and the title figuring on top of the first page. Use standard margins, double spacing, and "Times New Roman" size 12 as your font. Hand-written essays are not acceptable."

\subsection{Quizzes, Midterm, and Final Exam.}

This section provides students with information on how often you plan on testing them, on which specific dates, and what course materials and type of knowledge tests will cover. If you are planning pop quizzes, give students hints about the date range, the period when they should expect them which is fixed by the responsible of the LMD domain at the 
beginning of every semester. Specify the length of the tests, whether they will be taken at the beginning or at the end of the class, on an individual or group basis, and whether they will be oral, written, or a mixture of both. Davis (no date) suggests to give students copies of past tests and exams to help them better prepare for their own and to give them hints of what is expected of them. Communicate your course policy regarding missed quizzes and exams which should adhere to the LMD system regulations. Students with an excused absence have the right to redo the missed tests. A tip on a smooth way to schedule tests for absentees is to have them take the make-up exam along with indebted students while counting it as a regular session test for them. If you choose to do so, mention it in this section of the syllabus. In fairness to students, the LMD policy suggests that different teachers can't schedule more than two tests on the same day. If it happens that your tests coincide with two others, discuss with the concerned faculty the existing possibilities for altering the test date as an extraordinary condition and notify your students ahead of time so that they plan their review and preparation accordingly. The administration can help organize this procedure early in the semester upon submission of syllabi or in a faculty meeting.

\subsection{Oral Presentations and Writing Projects.}

Questions related to these assessment tools include the following: How many oral presentations and writing projects you are planning on giving? Will the topics be chosen in consultation with the teacher? What are the deadlines for topics approval and submission? What is the length of the writing project and the duration allowed for the oral presentation? What are the presentation dates? Are they to be done individually or as a peer work? Besides answering these questions, detail the criteria for grading oral and written projects. A presentation in an oral expression class might be graded based on the use of vocabulary, conjugation, pronunciation, fluency and accuracy, understanding and answering questions, organization, and appropriate length. Papers in a composition classroom might be graded based on organization (introduction, body, and conclusion), use of connectors, legibility, development of ideas, coherence and cohesion....etc. Instructions on how to write them are useful ( e.g., precise the number of words they should contain, whether they should be typed or hand-written, whether or not you tolerate typos, and whether the assignments are due at the beginning or at the end of the class time). Make it clear to students if they have to cite any material borrowed from other sources and if you offer extra credit for neatness, clarity of handwriting, and organized papers.

\subsection{Group Work.}

Of the different possible assessment types aforementioned, teamwork is the most challenging to grade fairly in that it is the fruit of a collective contribution of students, who might more or less put different amounts of effort into the assigned work. We often have students complain about the mediocre or void contribution of their peers to a group work they should equally take part in doing. We as teachers have experienced this when students. As is the case for other types of assessment, providing a detailed description of the tasks students are expected to fulfill and setting clear criteria and rubrics for grading them is the first step towards a fair grading of teamwork. Some faculty provide students with a peer evaluation sheet to track the contribution of each one of them and advise those team members who are not contributing enough before setting their final grade. Students are asked to be fair and honest in evaluating each other's degree of cooperation, willingness to carry out the tasks assigned, as well as the quality of the job provided. Faculty who do this can arrange meetings with the whole group to check the validity of the peer evaluation students provided for each other (Brown, 2005). Except for those who proved passive and reluctant, the same grade is granted to members of the same team (Slattery \& Carlson, 2005, p. 161C -162A).

\section{The Grading Scale.}

For the assessment recipe to be complete the proportional amounts of ingredients need to be accurately measured and the doses clearly prescribed. Explain in details how much every assignment is worth. In conformity with the scale approved by the Ministry of Higher Education and Scientific Research for the Licence in English in El Tarf University, for example, final exams weigh 70 percent of the overall course grade for all courses alike. The remaining 30 percent is left to every teacher to divide on the number and types of assignments he judges suitable for his course. Detail how you will compute the final course grade (e.g., continuous evaluation= (attendance and participation 5\%+homework $10 \%+$ midterm $15 \%) * 0.3+($ final) $* 0.7)$. Tell students how they should expect to receive their grades: In class only, in class and on the bulletin board, posted on your own webpage or on the course webpage you might have created. You can annex to the syllabus tables that summarize the important dates, grades distribution, and grading scale, if any. Add a note on whether or not you will curve grades in your course and request that complaints about grades miscalculation have to be addressed directly to the professor rather than rushing to contact the registrar's office or the department's administration in the first place.

\section{H. Classroom and LMD System Policy}

\section{Conduct.}

Students are expected to show respect to their teachers as well as their peers. Violating good conduct rules exposes them to disciplinary actions determined by the LMD system policy which should be detailed on the syllabus due to students' ignorance of or lack of information about the system. Instructions on bringing food and drinks to class, on wearing suitable attire, and on using cell phones, laptops, MP3s, MP4s, and other electronic devices are useful to include (Johnson, 2006). Also, be clear about your policy with talkative students.

\section{Cheating in Exams.}


Give students a link to access the LMD system policy regarding cheating in exams or include it in this section of your syllabus.

\section{Scheduling Make-up Sessions.}

In this part, tell your students how they will be informed of the make-up sessions: In class, through announcements on the bulletin board, or through the delegate of the group. State whether or not you allow a student with unexcused absences to make up for missed sessions with a different group. If you don't accept to host students in a class other than theirs, make it clear to them that they have to stick to their group.

\section{Make-up Exams.}

Inform your students that there is a separate make-up exam for every semester of study. Make it clear to them that only students who don't get a passing grade in the course are eligible to take it. The make-up exam isn't meant for students willing to improve their grades.

\section{Student Guests.}

Indicate whether you allow occasional visits by students who are not enrolled in classes you teach. Tell students to ask for your permission prior to inviting people to attend your course and make it clear to them that guests have to abide by good conduct etiquette.

\section{Students with Chronic Diseases.}

Bring it to the attention of students with chronic diseases that they have to inform both their instructor and the administration right from the beginning of the semester of their health condition. Assure them that the information they release to you regarding their health issues remains confidential.

\section{Tips to Succeeding in the Course.}

Students appreciate it so much if you guide them with tips and advice that you judge key to success in your course.

\section{Resources and Services.}

Sharing information with your students regarding campus instructional resources and services---including the library, media library, IT (Information Technology) and AV (Audio-visual) services, print shops, computer or internet rooms, health center, counseling and psychological services, and tutorial sessions--- tells you care enough about them not only inside but also outside the classroom and that you are ready to help by any possible means.

\section{RECOMMENDATIONS}

1. Have a colleague review the syllabus for you before discussing it with your students. He might pay attention to something you might have missed (Matejka \& Kurke, 1994, p.116B; Woolcock, 2006, p. 26).

2. Share the syllabus with students on the first meeting. At the very latest, don't exceed the second week of classes to hand it over. Repetitive reminders and constant warning statements remain necessary throughout the semester. Keep reminding your students of important dates. While they have the syllabus at hand, they might forget.

3. Encourage students to consult the syllabus on a regular basis, especially those who miss the first class.

4. Leave a hard copy with the delegate of every group you are teaching so that students can make copies in case they lose their own. Ideally, publish it on the university's website or on the web page you might have created for instructional purposes.

5. Maintaining a friendly tone in the syllabus is more fruitful than the rigid instructions that put barriers between you and the student and intimidate him (Davis, no date, Developing Your Syllabus and Career, 2012).

6. Make your syllabus as detailed and as clear as possible using a language that is accessible to your students. Remember that it is not the best document to show your bulging and rippling language muscles.

7. An effective syllabus should not be too long to avoid the danger of boredom and not too short to the point that many points are left dismissed and untreated.

8. Adding pictures, cartoons, and graphics related to the course subject and content adds a creative touch to the syllabus (Sinor \& Kaplan, no date).

9. Although not compulsory, you can have students sign their names in a sheet of paper for receiving, reading, and understanding the syllabus (Matejka \& Kurke, 1994, p.115B).

10. Commit to it and if you intend to make any changes, inform students ahead of time and make sure everyone knows (Johnson, 2006). The syllabus loses its weight, caliber, and value if the professor doesn't adhere to it. This is not to discard flexibility and responsiveness when needed.

11. Keep up revising your syllabus and amending it as often as possible as the course progresses. Update it regularly when the semester unfolds. (Matejka \& Kurke, 1994, p.117B; Slattery \& Carlson, 2005, p. 163B).

12. Seek feedback from your students.

13. It is useful to set departmental guidelines for writing syllabi with a checklist to seek uniformity.

14. It is useful for teachers to take the phone number of one or two students in class -preferably the delegates of groups - to contact them in case unexpected tardiness or absence occurs or in case they need to communicate something urgent to students. 
Based on the core syllabus components sketched in the previous section of the present article, I will provide a sample syllabus that I use in my Level 1 phonetics classes and in which I address most of the overarching sections effective syllabi attend to. This sample is meant to assist and guide Algerian faculty in thoughtfully designing their own course syllabi and is by no means the word of the syllabus shell or content. Faculty might choose to prepare their syllabi in a different way, adding any information they judge key in their course outline and that best fit their class needs. I append to the syllabus a sample of a pick-up signature form that I usually require students to complete upon receiving a copy of the course syllabus.

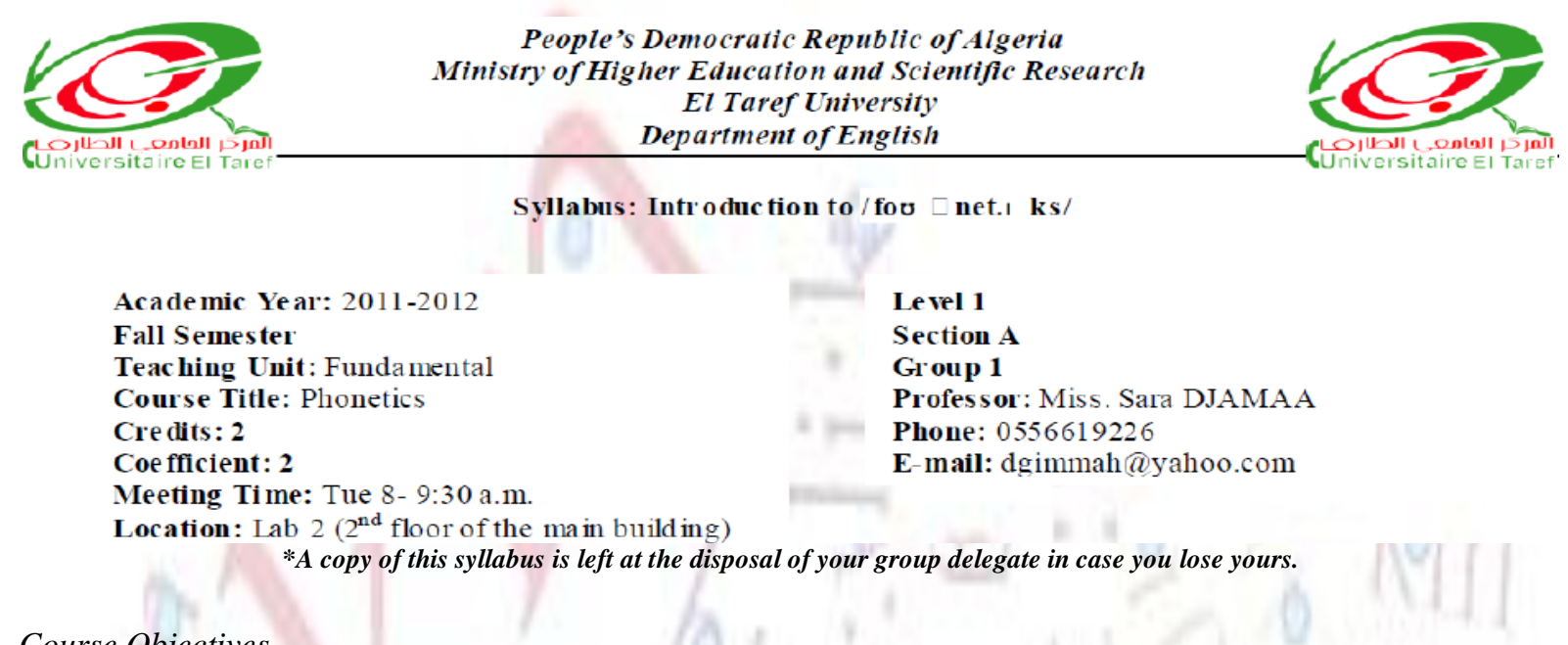

\section{A. Course Objectives}

This course is a theoretical-cum-practical introduction to articulatory phonetics. It begins by defining the different areas of the science of speech production and perception, scrutinizing the organs of speech and their function and classifying English sounds. After tackling some theory, the course shifts emphasis to teaching you to recognize and use the International Phonetic Alphabet (I.P.A) symbols. Transcription exercises and listening and pronunciation drills will be intensely introduced. The course culminates by shedding light on stress levels and placement rules, tone, intonation, pitch of the voice etc.

In light of these objectives, by the end of this course you will be able to:

1. Identify the different areas of phonetics and understand their main foci.

2. Describe the anatomy of speech and discover the contribution of each organ in the articulation of sounds.

3. Classify the English consonants in terms of voicing, escape channel, force, place, and manner of articulation.

4. Classify vowel $\mathrm{s}$ in terms of tongue height and backness and lips rounding.

5. Master the phonetic alphabet, read and produce transcribed English texts.

6. Examine stress levels and stress placement rules in English.

7. Examine the importance of using appropriate tone, intonation, and pitch of voice in different speaking contexts.

8. Improve your English pronunciation.

\section{B. Course Approach and Methodology}

The first segment of the course takes the form of lectures with a variety of slide shows, videos, and handouts incorporated into the lessons. Once the theoretical portion of the syllabus wrapped up, the sessions will be held in the lab where the teacher will be guiding you through practice. You will be listening to native speakers and rehearsing after them as you will be asked to practice reading aloud English words, expressions and sentences both in regular spelling and transcription forms. You are expected to take an active role in the classroom by coming prepared for the lectures and by fully engaging in practice during the lab sessions. The following steps will help you prepare for class:

1. Accomplish the readings recommended to you by your professor and seek answering the assigned questions prior to coming to class.

2. Conduct online research on the topic that constitutes the main concern of a particular lecture. Useful website links will be communicated to you by your professor.

3. Practice reading the words and expressions on the handouts until you familiarize yourself with accurate pronunciation.

4. Practice transcribing as many words, expressions and tests as you can until you acquaint yourself with the phonetic alphabet symbols.

\section{Course Materials}

There are no textbooks or materials required for this course. However, the following references are highly recommended in that they help you prepare for your classes ahead of time and are useful for exam preparation and reviews: 
1. Adamczewski, H., and D. Keen. Phonétique et Phonologie de l'Anglais Contemporain. Armand Colin, 1982.

2. Bowen, J.D. Patterns of English Pronunciation. Newsbury House Publishers, n.d.

3. Carr, Philip. English Phonetics and Phonology: An Introduction. 2nd ed.Wiley-Blackwell, 2012.

4. Gimson, A.C. An Introduction to the Pronunciation of English. 2nd ed.Edward Arnold, 1970.

5. Guierre, L. Drills in English Stress-Patterns. Longman, 1965.

6. Jones, Daniel. Cambridge English Pronouncing Dictionary. 2011. Ed. Peter Roach, Jane Setter and John Esling. 18th ed. Cambridge UP.

7. Ladefoged, Peter, and Keith Johnson. A Course in Phonetics. 6th ed. Wadworth, 2010.

8. O'Connor, J.D. Phonetics: A Simple and Practical Introduction to the Nature and Use of Sound in Language. Penguin Books Ltd, 1973.

9. Ogden, Richard. An Introduction to English Phonetics. Edinburgh UP, 2009.

10. Prator, Clifford H., and Betty Wallace Robinett. Manual of American English Pronunciation. 4th ed. HRW International Editions, 1985.

11. Sethi, J., and P.V.Dhamija. A Course in Phonetics and Spoken English. 2nd ed. PHI Learning Pvt. Ltd., 2004.

In addition to the suggested bibliography, supplementary handouts will be prepared by the professor and useful websites will be communicated to you concurrently with the course progress.

D. Tentative Course Calendar

Oct. 4

Oct. 11

Oct. 18

Oct.25

Nov.1

Nov. 8

Nov.15

Nov.22

Nov.29

Dec. 6

Dec. 13

Dec.15

Jan.2

Jan.3

Jan.10

Jan.17

Jan.20

Jan.22-26

Jan. 29-Feb 9
Session 1: First class meeting Discussion of the syllabus

Session 2: 1. Definition of Linguistics

2. Branches of Linguistics

3. Definition of Phonetics

4. Areas of Phonetics

5. Articulatory Phonetics: The Speech Organs (Part 1).

Session 3: The Speech organs (Part 2).

Session 4: 6. An Introduction to the English Consonants:

6. a. The dichotomy between consonants and vowels

6. b. The Classification of the English Consonants:

6. b.1. Voicing

6. b.2. The position of the velum

6. b.3. The force of articulation

Session 5: Day off *No Classes*

The $57^{\text {th }}$ national anniversary of the Declaration of the Algerian Revolution War.

Session 6:

6.b.4. The Place of Articulation (Part 1).

In-Class Test 1 (10\% of the overall course grade)

Session 7: 6.b.4. The Place of Articulation (Part 2).

Answer key and feedback of test 1

Session 8: 6.b.5. The Manner of Articulation

Session 9: 7. An Introduction to the English Vowels:

The classification of the English Vowels

7. a. Height and backness.

Session 10: 7.b. Rounding

A comprehensive review

Session 11: 8. An Introduction to the International Phonetic Alphabet (I.P.A)

In-Class Test 2 (10\% of the overall course grade)

Winter break begins, 4:30 p.m.

Classes resume, 8 a.m.

Session 12: 8.1. / / / versus / / :/

8.2. / $/$ / versus / $\mathrm{v}: /$

Answer key and feedback of test 2

Session 13: 8.3. $/ \mathrm{p} /$ versus / $\mathrm{o}: /$

8.4. /æ/versus $/ a: /$

Session 14: 8.5. /^ / - /e/

8.6. $/ \mathrm{a} / \mathrm{arersus} / 3: /$

Fall semester classes end, 4:30 p.m.

* Course content to be continued in spring semester*

Reading period *No classes*

Final Exams

To be scheduled by the administration of the department. 


\section{E. The Grading System}

In conformity with the department of English Licence offer approved by the Ministry of Higher education for El Tarf University Center, continuous evaluation is worth $\mathbf{3 0 \%}$ of the overall course grade. As to the phonetics course, this attributed percentage will be distributed as follows:

1. In-Class Tests $(20 \%)$ :

There will be two in-class tests with each weighing $\mathbf{1 0 \%}$ of the overall course grade. The first test is scheduled for the sixth week of classes whereas the second will be held on the eleventh week. Both tests take place in the second half of the session and the time allotted to each is $\mathbf{4 5}$ minutes. You will be informed up front about the material these tests will cover.

\section{Attendance and Participation (10\%):}

Students are committed to attend all classes regularly. Attendance is worth 5\%. Abiding by the LMD system absenteeism policy, the course allows up to $\mathbf{0 3}$ unexcused absences or $\mathbf{0 5}$ excused ones per semester. Failing to honor this regulation will inevitably lead you to failing the course. Copies of justification forms have to be handed in to your professor the session following the one you miss. Submitting justification forms only to the registrar office doesn't guarantee your professor is apprised. Students are banned from interrupting the flow of the course when coming to class 15 minutes late. Both unexcused absences and ritualized tardiness may adversely affect students' grades.

Active vocal participation is paramount in this course if you are to fully benefit from it and internalize its material. Don't be shy or afraid to make mistakes for you learn from your errors as well as from those of your peers. Class participation is worth $\mathbf{5 \%}$ and will be evaluated based on the following criteria: Coming to class prepared, asking and answering questions, and commenting.

3. Final Exam (70\%):

The remaining $\mathbf{7 0 \%}$ of the course grade is attributed to the final Exam. This exam is comprehensive covering all the material the course equipped you with. The date of the final exam is to be scheduled by the department's administration. Thus, keep an eye on the announcements board when exams period approaches.

Based on the grades distribution detailed above, your final grade in this course will be calculated as follows:

$($ In-class test $1 / 20) \times 0.10+($ In-class test $2 / 20) \times 0.10+($ attendance/20 $) \times 0.5+($ class participation/20 $) \times 0.5+$ $($ Final Exam $/ 20) \times 0.7=$ Course grade $/ 20$

You will be able to check your tests and regular exam papers along with their answer key. Your final course grade will be communicated to you in class and/or posted on the department's bulletin board when the semester wraps up.

\section{Make-up Exams:}

These are to be scheduled by the administration of the department. There will be a separate catch-up exam for every semester of study. These exams are comprehensive and include all the material we cover during the target semester for which you are taking the exam. Make-up exams are not meant for students willing to improve their course average. They are strictly reserved to those students who fail the course. Unlike regular exams and tests, you do not have the right to consult you make-up exam paper in conformity with the LMD system exams policy. However, you are still reserved the right to check the answer key which will be posted on the department's bulletin board 72 hours after the exam date. The grade you get in the make-up exam substitutes the average of the course for the particular semester in which you failed it.

In this course, all assignments, tests and exams are out of a 20 point scale.

No grades will be curved in this course.

Any queries about course grades or complaints about miscalculation problems have to be reported directly to the professor. Do not address the department's administration or the registrar office regarding grades-related issues prior to negotiating them with your professor.

For information on the LMD system absenteeism policy, continuous evaluation process and exams regulations, refer to the following statutory text which is available online at: http://cruo.enset-oran.dz/spip.php?rubrique67.

- Arrêté $n^{\circ} 136$ du 26 Joumada Ethania 1430 H correspondant au 20 Juin 2009 fixant les règles d'Organisation et de gestion pédagogiques communes aux études conduisant aux diplômes de Licence et de Master.

\section{F. Course Policies}

\section{Conduct:}

Student-teacher and student-student mutual respect is vital to ensure a healthy and friendly learning environment. Students showing lack of respect towards their professor or peers are vulnerable to the penalties determined by the LMD system regulations with regard to misconduct. Foul language, rude behavior, harassment, intimidation, menaces, and ignorance of the teacher's instructions are only to mention a few of the forms of disrespect towards others in class.

Chatting in class while the lesson is in progress is disrespectful to your professor and distracting to your classmates. Talkative students run the risk of being expelled from class with their dismissal counting an absence. When excessive chatting occurs, chattier students become subject to severe disciplinary actions. 
Food and drinks are not permitted in class. The use of MP3s and MP4s is banned too. Because recent technological advances allow electronic dictionaries to be uploaded into cell phones, you are asked not to put your mobiles in the silent mode but rather to switch them off during regular class time as well as in tests and exams. Writing on tables, scratching and breaking the equipment is not tolerated.

\section{Honor Code:}

Students caught cheating in tests and exams get a zero in the assignment and are subject to severe disciplinary actions. Remember that the LMD system honor and misconduct code is in effect in this class.

\section{Make-up Sessions:}

You will be informed up-front both in class and through written announcements on the bulletin board about your teacher's scheduled absences. A catch-up session is due for every missed class. Its date, time, and locale will be communicated to you in the same way as the scheduled absence. Attendance will be recorded in make-up sessions. Students are required to stick to the group they belong to. Unless for a solid reason, you are not allowed to attend regular classes or make-up sessions with a group other than yours.

\section{Guest students:}

When seats are available in the classroom, students are allowed to occasionally bring guests with them on the condition that they show good conduct. If you consider inviting someone to class, ask your teacher for permission up front.

\section{Students with health problems:}

Students suffering from chronic diseases have to report their health condition to the department's administration as well as to the professor no later than the first month of classes. Be guaranteed that the information you release to your professor is meant to accommodate you and remains confidential.

\section{NB: This syllabus is subject to changes according to class needs}

-Best of Luck-

\begin{tabular}{|l|l|l|} 
IMPORTANT DATES! \\
\hline Week & Dates & Assignment \\
\hline 6 & Nov.8 & In-class test 1 \\
\hline 11 & Dec.13 & In-class test 2 \\
\hline 16 & TBA & Final Exam \\
\hline
\end{tabular}

\begin{tabular}{|l|l|}
\multicolumn{2}{l}{ GRADE DISTRIBUTION } \\
\hline Assignment & Percentage \\
\hline Test 1 & $10 \%$ \\
\hline Test 2 & $10 \%$ \\
\hline Attendance and Class Participation & $10 \%$ \\
\hline Final Exam & $70 \%$ \\
\hline
\end{tabular}

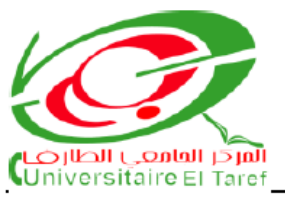

People's Democratic Republic of Algeria Ministry of Higher Education and Scientific Research El Taref University Center Department of English

Syllabus Pick-Up Signature For m

Academic Year: 2011-2012

Fall Semester

Course Title: Phonetics
Level 1

Group 1

Professor: Miss. Sara DJAMAA

\section{Instructions:}

Please, carefully read the instructions below. Sign your name and date your column.

By my signature

1. I certify that I have received a copy of the syllabus for the Phonetics course.

2. While my professor has exhaustively explained the syllabus in class, I understand that it is my responsibility to carefully go through it again, regularly review it, and keenly strive to abide by it.

3. I understand that failure to abide by the course policy highlighted in the syllabus is a violation of the contract agreement I set with my professor and that I, subsequently, will be treated and penalized exactly as is documented in the syllabus. 


\begin{tabular}{|c|c|c|c|c|}
\hline$\#$ & Registration \# & Student's Full Name & Signature & Date \\
\hline 01 & $09 / 6033339$ & ATI SAMIRA & & \\
\hline 02 & $08 / 6046340$ & ALZEHYRIE SALI & & \\
\hline 03 & $08 / 6046481$ & BOUZATA IMANE & & \\
\hline 04 & $09 / 6033864$ & BENTRADE HANANE & & \\
\hline 05 & $09 / 6034378$ & BOUYAKOUB ISLAM SARA & & \\
\hline 06 & $02 / 656520$ & BOUZIANE AKILA & & \\
\hline 07 & $00 / 653987$ & CHAIB NAWEL MERIEM & & \\
\hline 08 & $09 / 6033333$ & DAOUDI ZINEB & & \\
\hline 09 & $09 / 5001088$ & DARZEHAF SARA & & \\
\hline 10 & $96 / 311133$ & DERDEZI MERIEM & & \\
\hline 11 & $08 / 6046603$ & DIABI FOUZIA & & \\
\hline 12 & $08 / 6033790$ & DJAMAA SOUMIA & & \\
\hline
\end{tabular}

\section{Final Thoughts}

Algerian faculty should rush to include the syllabus as an overarching component of their courses if they are to bolster both teaching and learning effectiveness. We need to raise awareness that the conception of the syllabus as the course table of contents dates back to the dim past and that the current educational ideology imposes new legislations that we are entitled to abide by if we seek excellence in teaching and quality learning. It is my belief that the absence of course syllabi from our teaching practices is a pedagogical sin and a serious ethical issue that we need to remedy soon. By failing to honor the syllabus, we are conspiring against students' growth and success and depriving ourselves from leading better careers. Thus, let us use it, value it, cherish it, teach and learn best through it.

\section{APPENDIX. ACADEMIC WARNING FOR ABSENTEEISM}

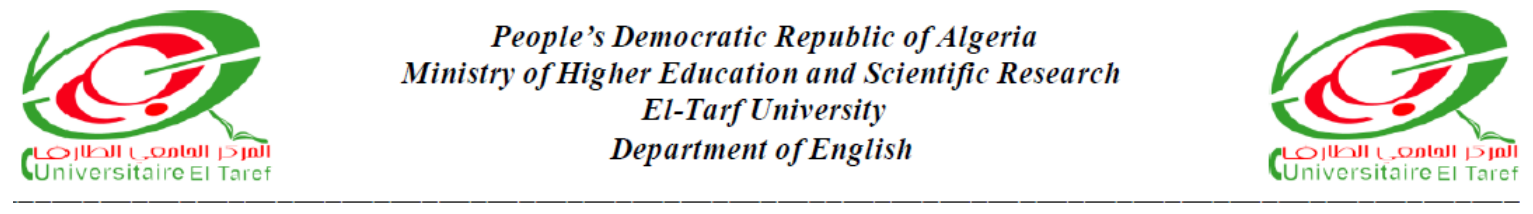

إنذار بالغياب

Academic Warning for Absenteeism

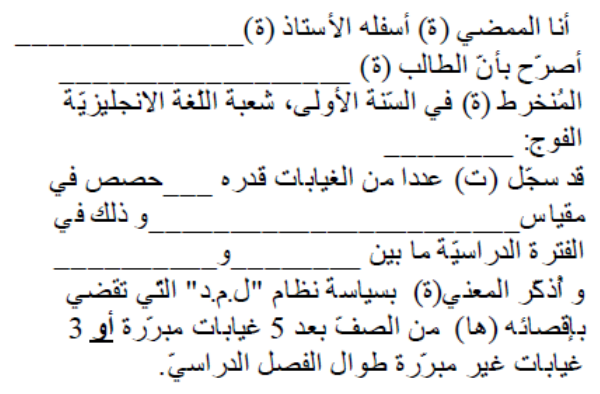

إمضاء الأستاذ (ة) المعني (ة):

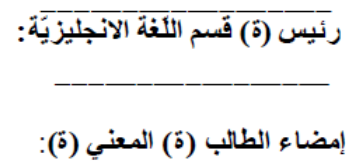

I, the undersigned, profess or

Declares that the student

Currently enrolled in freshmen English classes Group \#

Has reached absences

In the _________________ course

During the academic period between __ \& and I, hereby, remind the concerned of the LMD system attendance policy that dictates failing a student in a course after 5 excused or 3 unexcused absences per semester.

Professor's Signature

Department Chair

Student's signature

\section{ACKNOWLEDGMENT}

Credit is granted to the related published scholarship cited in the reference section of the article in that it helped as a basis to shape the syllabus content in the Algerian Higher education context. Special thanks go to Soumaya Djamàa, a freshman student of English at Badji Mokhtar-Annaba University who contributed in critiquing the article from a student perspective. 


\section{REFERENCES}

[1] Altman, H. B. \& W. E. Cashin. (1992). Writing a syllabus. Idea paper, No. 27. Manhattan: Center for Faculty Evaluation and Development, Kansas State University.

[2] Altman, H. B. \& W. E. Cashin. (n.d.). Writing a syllabus article. Minnesota State University. Retrieved September 18, 2012 from http://www.mnsu.edu/cetl/teachingresources/articles/syllabus.html.

[3] Brown, A. (2005). BUAD477: Information technology applications in marketing. Syllabus Retrieved September 22, 2012 from http://www.udel.edu/alex/pdf/Syllabus.pdf.

[4] Center for Teaching Excellence, Duquesne University. (n.d.). Developing your syllabus and career. Retrieved September 20, 2012 from http://www.duq.edu/about/centers-and-institutes/center-for-teaching-excellence/teaching-and-learning/developingyour-syllabus-and-career.

[5] Center for Teaching Excellence, Duquesne University. (n.d.). The importance of the course syllabus. Retrieved September 20, $2012 \mathrm{from} \mathrm{http://www.duq.edu/about/centers-and-institutes/center-for-teaching-excellence/teaching-} \mathrm{and-learning/importance-}$ of-the-course-syllabus.

[6] Center for Teaching Support and Innovation, University of Toronto. (n.d.). Developing course syllabi. Retrieved September 28, 2012 from http://www.teaching.utoronto.ca/topics/coursedesign/course-syllabi.htm.

[7] Davis, M. (n.d.). Designing a course syllabus. Kansas State University. Retrieved September 30, 2012 from http://www.kstate.edu/catl/edci943/designsyllab.htm.

[8] Johnson, C. (2006). Best practices in syllabus writing. The Journal of Chiropractic Education, 20.2, 139-144. Retrieved September 25, 2012 from http://www.ncbi.nlm.nih.gov/pmc/articles/PMC2384173/.

[9] Matejka, K. \& L. B. Kurke. (1994). Designing a great syllabus. College Teaching, 42.3, 115-118.

[10] Sinor, J. \& M. Kaplan. (n.d.). Creating your syllabus. Center for Research on Learning and Teaching. University of Michigan. Retrieved September 28, 2012 from http://www.crlt.umich.edu/gsis/p2_1.

[11] Slattery, J. M. \& J. F. Carlson. (2005). Preparing an effective syllabus. College Teaching 53.4, 159-164.

[12] Woolcock, M.J.V. Constructing a syllabus. (2006). $3^{\text {rd }}$ edition. The Harriet W. Sheridan Center for Teaching and Learning. $\begin{array}{llllll}\text { Brown University. } & \text { Retrieved } & \text { July } & 2012 & \text { from }\end{array}$ http://www.brown.edu/Administration/Sheridan_Center/docs/construct_syllabus.pdf.

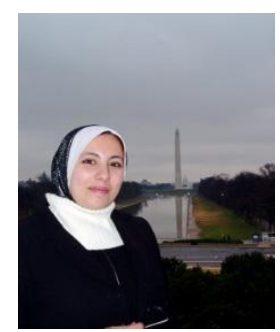

Sara Djamàa was born in Annaba, Algeria on December 6, 1982. She was educated at Badji MokhtarAnnaba University where she received her BA in English Language and Literature with distinction. She passed the competitive national Magister examination at Béjaia University where she obtained her Magister degree in TEFL (Teaching English as a Foreign Language) with distinction. She then left to the States where she took non-degree courses at Hamilton College in New York for two years. Miss. Djamàa is now preparing her PhD thesis on adapting film adaptations in the Literature Classroom to hone EFL students' critical writing skills.

Besides teaching in middle and high schools in Algeria, she also worked for the Departments of English at the University of Béjaia, Annaba, and El-Tarf for the past five years. She also occupied the position of Head of Department for two years and has been elected as President of the Scientific Committee of the Department of English and member of the Scientific Council of the Faculty of Letters and Languages in El- Tarf University.

Miss. Djamàa is a member of the IATEFL (International Association of Teachers of English as a Foreign Language). 